\title{
First reports of Megamouth Shark, Megachasma pelagios Taylor, Compagno \& Struhsaker, 1983 (Lamniformes, Megachasmidae), in Peru
}

\author{
Shaleyla Kelez ${ }^{1}$, Rossana Maguiño Napuri ${ }^{1}$, Alejandra Mendoza Pfennig ${ }^{1}$, \\ Oswaldo Caldas Martinez ${ }^{2}$, Antonio Torres Carrasco ${ }^{3}$
}

1 ecOceánica, Calle Copernico 179, San Borja, Lima, Peru. 2 Pesquera Hayduk S.A., Av. Manuel Olguín 501, Oficina 701, Santiago de Surco, Lima, Peru. 3 Planeta Oceano, Malecón Armendáriz 199, dpto 201, Miraflores, Lima, Peru.

Corresponding author: Shaleyla Kelez, shaleyla.kelez@ecoceanica.org

\begin{abstract}
Megamouth Shark, Megachasma pelagios Taylor, Compagno \& Struhsaker, 1983, is one of the least-known shark species worldwide. We report the encounters of four megamouth sharks: one caught in a driftnet off Piura (November 2016; sex indeterminate), one landed in Los Organos (July 2018; female), one stranded in El Nuro (July 2018; sex indeterminate, ca $300 \mathrm{~m}$ total length), and one caught in a purse seine off Lambayeque (June 2019; female, total length ca $300 \mathrm{~cm}$ ). These are the first records from Peru and expand the species' known southern limit by $415 \mathrm{~km}$. With the addition of M. pelagios, there are 67 species of sharks in Peru.
\end{abstract}

\section{Keywords}

Bycatch, elasmobranchs, range extension, strandings.

Academic editor: Arturo Angulo | Received 19 June 2020 | Accepted 3 October 2020 | Published 15 October 2020

Citation: Kelez S, Maguiño Napuri R, Mendoza Pfennig A, Caldas Martinez O, Torres Carrasco A (2020) First reports of Megamouth Shark, Megachasma pelagios Taylor, Compagno \& Struhsaker, 1983 (Lamniformes, Megachasmidae), in Peru. Check List 16 (5): 1361-1367. https://doi.org/ $10.15560 / 16.5 .1361$

\section{Introduction}

There are currently 66 shark species recorded in Peru. They comprise coastal to oceanic sharks and include highly fished species such as Blue Shark (Prionace glauca (Linnaeus, 1758)) as well as rare species like Pacific Sleeper Shark (Somniosus pacificus Bigelow \& Schroeder, 1944). With 31 species considered commercially important, Peru has a large shark fishery at the regional level (Gonzalez-Pestana et al. 2016); for example, 10,715 $\mathrm{t}$ of shark catches were reported in 2010 (Fischer et al. 2012). However, research and knowledge on these species is still limited, and there are large information gaps for most shark species in Peru. The tropical marine ecosystem on Peru's northern coast has the greatest diversity of elasmobranchs in the country and is where researchers are finding new and important information on this group (e.g. Mendoza et al. 2017; Alfaro-Cordova et al. 2018; Gonzalez-Pestana et al. 2019). However, this ecosystem also has an uncontrolled and unsustainable fishery which threatens many species, not only sharks.

Megamouth Shark, Megachasma pelagios Taylor, Compagno \& Struhsaker, 1983, is one of the lesserknown sharks globally. This species was described only 
in 1983 (Taylor et al. 1983), and only 135 individuals have been reported to date (Martinez-Ortiz et al. 2017; Liu et al. 2018; Haight 2019; https://www.floridamuseum.ufl. edu/discover-fish/sharks/megamouths/). It occurs in all tropical and temperate seas of the world except the Western Indian Ocean (Morrissey and Elizaga 1999; Ebert et al. 2013). Most reports come from strandings or from bycatch in commercial fisheries. A recent genetic analysis shows that there is no genetic structure and that the population can be considered panmictic (Liu et al. 2018) until more detailed genetic studies show otherwise. Megachasma pelagios, which specializes in eating plankton, is the smallest of the three currently described filter-feeding sharks; it can reach a total length of $710 \mathrm{~cm}$, with females larger than males (Watanabe and Papastamatiou 2019). This species makes daily vertical migrations; it occurs at an average depth of $20 \mathrm{~m}$ at night and $150 \mathrm{~m}$ during the day (Nelson et al. 1997).

Most of records of $M$. pelagios are in the Pacific Ocean, but mainly from the western side, with Taiwan accounting for $42 \%$ of the records. In the Eastern Pacific Ocean, there are only 13 records: five from California (USA), four from Mexico, and four from Ecuador. Here, we report the first four records of $M$. pelagios in Peru, extend the southern limit of this species by $415 \mathrm{~km}$, and increase the number of shark species in Peruvian waters to 67 .

\section{Methods}

There are two marine provinces in Peru (Spalding et al. 2007): Warm Temperate Southeastern Pacific Province, which extends along $70 \%$ of the Peruvian coastline, and the Tropical East Pacific Province located in the north of the country. The Tropical East Pacific Province is divided into eight marine ecoregions, with the Guayaquil ecoregion being the one located in Peru. Our findings were located in the Guayaquil ecoregion, specifically in the north of Piura and Tumbes (from $4.27^{\circ} \mathrm{S}$ to $3.39^{\circ} \mathrm{S}$ ), in the mixing area between the two marine provinces and in the northern part of the Warm Temperate Southeastern Pacific Province.

Since 2017, the non-profit organization ecOceánica has periodically monitored elasmobranch landings at some artisanal fishery landing sites in northern Peru. The most visited landing sites were Puerto Pizarro, Zorritos, Acapulco, Cancas, Mancora, and Los Organos. EcOceánica also periodically monitors wildlife strandings of marine turtles, marine mammals, and sharks at some beaches in northern Peru. During this monitoring, information such as species, sex, and morphometric data were collected; for sharks the collection of morphometric data followed the protocols of Compagno (2001). Photographs are taken, and, in some cases, tissue samples are collected which are preserved in $96 \%$ ethanol and then frozen. In the case of landings of elasmobranchs, information is collected about the fishing activity that lead to their capture. This monitoring is carried out in collaboration with the fishers and/or buyers of the specimens. In the case of strandings, the date, place (latitude, longitude), species, and state of decomposition are also documented.

For DNA analysis, the samples were brought to the lab and were tapped on kimwipe paper to remove excess liquid. Using sterile scissors, $40 \mathrm{mg}$ of tissue were excised and rinsed three times with sterile ultrapure water to remove excess ethanol. DNA was then purified using the GeneJET Genomic DNA Purification Kit (Thermo Fisher Scientific, Waltham, MA, USA) following the manufacturer's instructions. DNA yields were quantified using the Qubit ${ }^{\circledR} 2.0$ Fluorometer (Invitrogen, Carlsbad, CA, USA). The cytochrome c oxidase I (COI) barcode region was amplified following Ivanova et al. (2007). PCR products were cleaned with exonuclease and alkaline phosphatase (thermo) following the manufacturer's guidelines and then sequenced using the Sanger method at Macrogen Corp. Resulting DNA sequences were verified for quality scores. Low quality bases at the 5'- and 3'- ends were trimmed and contigs were made using the CodonCode Aligner Software (Centerville, MA 02632). Identifications were made by querying sequence contigs using the BOLD Systems Database for Animal Identification Tool using COI and by nucleotide BLAST searches using the Standard Nucleotide BLAST from NCBI; sequences were queried against the nucleotide collection database optimized for highly similar sequences (megablast).

A map was prepared to show the location of the four new records (Fig. 1).

\section{Results}

New records. PERU $\bullet 1$ sex indeterminate; Piura region, Paita district, Yacila (offshore); 21 Nov. 2016; Antonio Torres Carrasco observer; incidentally caught in an artisanal driftnet (Figs 1, 2A). $1 \hat{\jmath}$, interdorsal length 51 $\mathrm{cm}$; Piura region, Los Organos district (7.5 nautical miles [ 14 km] offshore); depth 146 m; 11 Jul. 2018; Nina Cristiano leg.; incidentally caught in a bottom gillnet (Figs 1, 2B). - 1 sex indeterminate, total length ca $370 \mathrm{~cm}$; Piura region, Los Organos district, El Ñuro; $4.2148^{\circ} \mathrm{S}$, 081.1720 W; 25 Jul. 2018; Araceli Torrejon, Nias Hernandez, and Rossana Maguiño leg, stranded (Figs 1, 2D). - 1 , , total length ca $300 \mathrm{~cm}$; Lambayeque region, south of Lobos de Tierra Island; $6.6133^{\circ} \mathrm{S}, 080.7686^{\circ} \mathrm{W} ; 12$ Jun. 2019; Oswaldo Caldas Martinez observer; incidentally caught in an industrial purse seine (Figs 1, 2C).

Additional information on each of these records follow:

- The specimen from 21 November 2016 was captured with a driftnet by an artisanal vessel targeting sharks (Prionace glauca; Shortfin Mako, Isurus oxyrinchus Rafinesque, 1810; and Smooth Hammerhead, Sphyrna zygaena (Linnaeus, 1758)). The vessel departed from Yacila (Piura region). The specimen was captured during a fishing set that was in the water from 16:51 


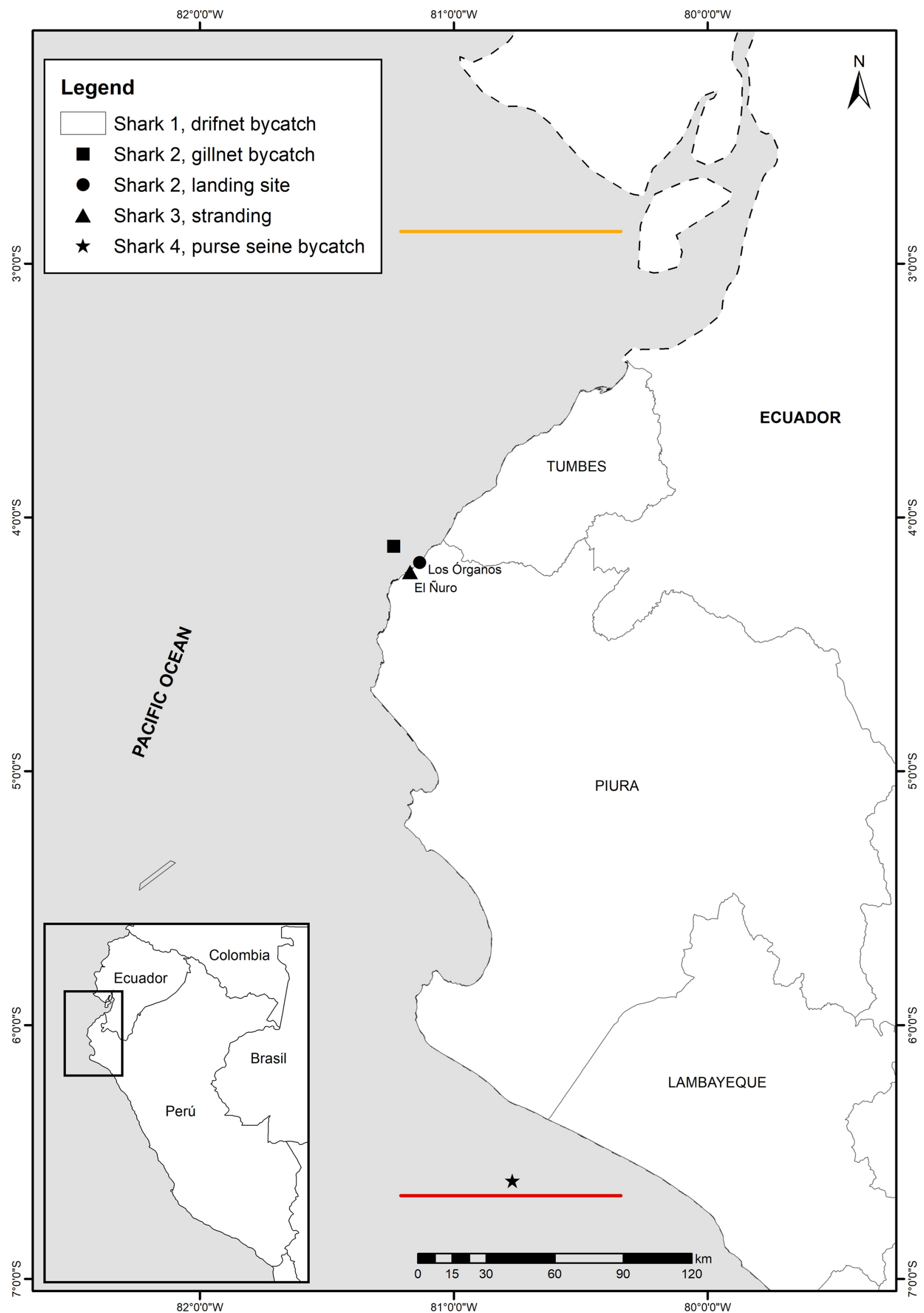

Figure 1. Map showing the location of the four Megachasma pelagios encounters in Peru. Empty polygon: driftnet set fishing area where the first specimen was caught, square and circle: bycatch and landing site of the second specimen, respectively, triangle: stranding site of the third specimen, star: purse seine set location where the fourth specimen was incidentally captured. The orange line marks the previous southernmost limit. The red line is the new limit. 

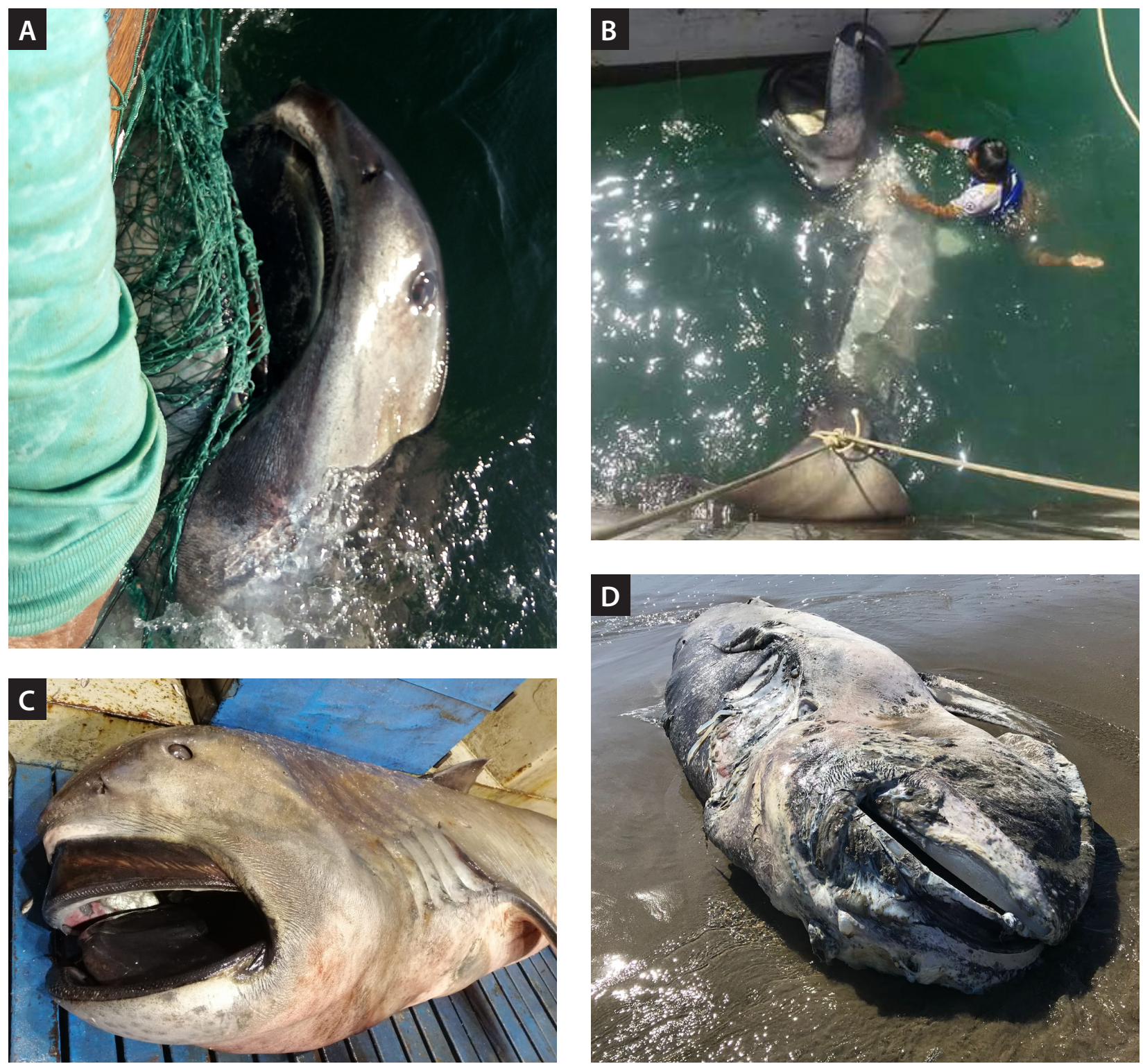

Figure 2. Megamouth Shark captures in Peru. A. Incidentally captured in a driftnet off Piura. B. Being lifted from a vessel to the Los Organos landing site, Piura. C. Captured by a purse seine net off Lambayeque. D. Stranded at El Ñuro, Piura.

to $17: 19 \mathrm{~h}$; the retrieval of the net started at $06: 06 \mathrm{~h}$ at $05.4428^{\circ} \mathrm{S}, 082.2357^{\circ} \mathrm{W}$ and effectively finished at 09:01 $\mathrm{h}$ at $05.4685^{\circ} \mathrm{S}, 082.2390^{\circ} \mathrm{W}$. The exact location of the encounter was not recorded (Fig. 1). The shark was alive and entangled in the driftnet, but fishers removed the gear and released the shark. The fishing crew was familiar with $M$. pelagios, which they call "bocón" (big mouth), and usually release, claiming the meat is watery and not palatable (Fig. 2A). The presence or absence of claspers could not be evaluated, so the sex was not determined. Tissue samples were not collected from this individual.

- The specimen from 11 July 2018, was landed at the Los Organos artisanal landing site after capture offshore (Figs 1, 2B). The shark's head was cut off and the specimen was cut up and marketed by fishers. The only obtained measurements are in Table 1 . The shark was unknown to most local fisherfolk (some thought it was Whale Shark, Rhincodon typus A. Smith, 1828).
Tissue samples were collected.

- The specimen from 25 July 2018 was in a high degree of decomposition, so the total length is an estimate. No more body metrics could be taken, nor the sex observed. Tissue samples were collected.

- The specimen from 12 June 2019 was incidentally caught by industrial purse seine net fishing for Anchoveta, Engraulis ringens Jenyns, 1842. The total length of this specimen is an estimation, as fishers did not have a measuring tape but used their own height

Table 1. Body metrics of the megamouth shark landed in Los Organos, Piura.

\begin{tabular}{lc}
\hline Body metrics & Length $(\mathbf{c m})$ \\
\hline Interdorsal length (IL) & 51 \\
Alternate length (AL) & 120 \\
Pectoral-anal length (PAL) & 160 \\
Clasper outer length (CLO), right & 45 \\
Clasper outer length (CLO), left & 51 \\
\hline
\end{tabular}


as a reference. After releasing it from the seine, it was photographed and set free. Tissue samples were not collected from this specimen.

Identification. All individuals were positively identified as $M$. pelagios by the following morphological characteristics: very large and long head, short and rounded snout, huge terminal mouth which extends behind the eyes, moderately long gill slits, two relatively small dorsal fins and an anal fin (Castro 1983; Compagno 2001; Compagno et al. 2005). Our analysis of the COI gene confirmed that the individual landed at Los Organos is M. pelagios. However, the DNA of the stranded individual was highly degraded and was unusable. Nonetheless, using photographs Dr David Ebert confirmed the identification of both specimens from July 2018.

\section{Discussion}

The four new records of Megachasma pelagios are the first from Peruvian waters and increase the number of shark species reported in the country to 67 . These records also expand the known distribution of this species 415 $\mathrm{km}$ south of the Ecuador-Peru border. Moreover, these are the 14th to 17th records from the Eastern Pacific Ocean, and they increase the global number records to 139. Although these records are the first scientific reports in Peru, some fishers from Los Organos said it was not the first time they have seen this species of shark, which they call "chirimoya" or "cherimoya" shark. Some fishers even reported seeing it as much as 15 years ago, and it may be more common than thought. Additionally, fishers from Yacila were familiar with this shark, which they call "bocón" (big mouth), but they mentioned that they rarely see it.

The capture of these sharks with three different types of fishing gear coincides with the daily vertical movement patterns of the species (Nelson et al. 1997). The bottom gillnet off Los Organos was at a depth of $146 \mathrm{~m}$ (80 fathoms), which is within the species' daytime depth range (i.e. $120-166 \mathrm{~m}$, mean $=149 \mathrm{~m}$ ) when it is at greater depths (Nelson et al. 1997). In the purse seine capture, the net was placed at night (22:20 h) and extended down to $119 \mathrm{~m}$, so it captured the shark during the time when $M$. pelagios is typically closer to the surface. The shark caught in the driftnet was also in shallower water; the gear was set between 16:51 $\mathrm{h}$ and 17:19 $\mathrm{h}$ at the surface and extended down to $20 \mathrm{~m}$ and was retrieved between 06:06 $\mathrm{h}$ and 09:01 $\mathrm{h}$ on the following day.

The specimen stranded at El Nuro had an estimated total length (TL) of $370 \mathrm{~cm}$, which would indicate that it was a juvenile but close to sexual maturation (length at first maturity Lm50 for males $=4.26 \mathrm{~m}$ in TL; females $=$ $5.17 \mathrm{~m}$; Watanabe and Papastamatiou 2019). To estimate the total length of the Los Organos specimen, we compared its interdorsal length (IL, Table 1) with the data of other male sharks as presented by Castillo-Géniz et al. (2012). Considering that the IL is between $12.4 \%$ and
$14 \%$ of the total length in this species, the TL of the shark from Los Organos could have measured between 364 and $411 \mathrm{~cm}$, which is close to adult size. The large size of the claspers also suggests an adult individual (Table 1). The shark captured by the purse seine was not properly measured, but it was estimated to over $3 \mathrm{~m}$, a juvenile size. The individual captured in the driftnet was also estimated to be around $3.5 \mathrm{~m}$ long.

Zooplankton - the preferred prey of $M$. pelagiosshows high biovolumes along the Peruvian coast between the $04^{\circ} \mathrm{S}$ and $06^{\circ} \mathrm{S}$ (Ayón et al. 2008), which is the area where all four specimens were recorded. The high biovolumes of zooplankton might be influenced by the presence of the Equatorial Surface Water, which is a warm and low salinity water mass with larger species and a high zooplankton diversity (Ayón et al. 2008).

An interesting facet of the new records is the temporal proximity of those from 2018; both encounters occurred only two weeks apart in July 2018. July is in the middle of the austral winter in northern Peru. On 11 July 2018, the sea surface temperature (SST) was recorded between 19 and $22{ }^{\circ} \mathrm{C}$ with positive anomalies (HIDRONAV 2018a); and on 25 July 2018, the SST was between 18 and $19{ }^{\circ} \mathrm{C}$ with neutral anomalies of \pm 0.5 ${ }^{\circ} \mathrm{C}$ (HIDRONAV 2018b). The purse seine report is from 12 June. 2019 (late fall in the southern hemisphere), and the SST was $19.1{ }^{\circ} \mathrm{C}$, as measured by the fishing vessel. The SST on 21 November 2016 off Piura was $18{ }^{\circ} \mathrm{C}$ (HIDRONAV 2016) during late spring. Watanabe and Papastamatiou (2019) mentioned possible seasonal latitudinal migration of $M$. pelagios, with a greater number of individuals in low latitudes during winter. Three of the four encounters in Peru were at low latitudes during colder months.

The only other reports in the Southeast Pacific region have been in Ecuador $(n=4)$ in areas near the border with Peru (Romero and Liza 2004; Martínez-Ortiz et al. 2017). These reports occurred in November, February, and March. When combining all reports from Peru and Ecuador to search for a seasonal pattern, the data show a regular pattern with a peak every three months (Fig. 3). Zooplankton studies off Paita (Piura) showed a seasonal abundance peak during austral spring and autumn which will coincide with two of the three observed peaks. It seems that zooplankton levels are higher during intermediate-strength upwelling events, as opposed to upwelling events that are too strong or too weak (i.e. during the winter and summer, respectively) (Aronés et al. 2009).

Another possibility for the presence of these sharks during winter is that they may be targeting small fishes, another of their prey items besides zooplankton (Last and Stevens 1994). The first individual found in Ecuador was observed regurgitating fish, mainly Engraulis ringens (Romero and Liza 2004). Engraulis ringens is distributed from Chile to Zorritos, northern Peru, and generally has a high abundance in winter with a spawning peak at the end of this season (Passuni et al. 2016). Future study would be useful to elucidate if there is a 


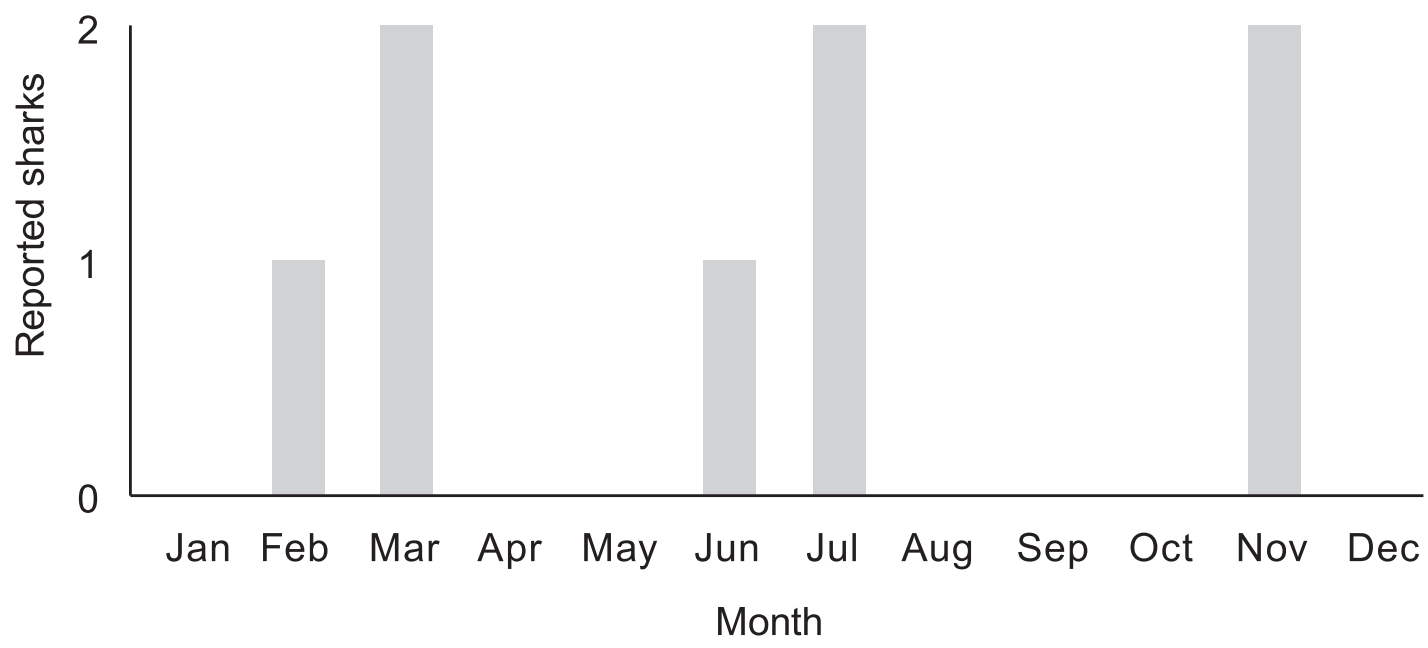

Figure 3. Monthly frequency of Megamouth Sharks reported in Peru and Ecuador $(n=8)$.

season when $M$. pelagios might prefer to move closer to the coast of the Eastern Pacific.

Megachasma pelagios is categorized as Least Concern by the IUCN (Kyne et al. 2019) due to its wide range and limited interactions with fisheries. However, its rarity might be the reason for those limited interactions, and considering its biological sensitivity to overexploitation (Dulvy et al. 2014), there have been recent concerns about its interactions with fisheries in Asia (Kyne et al. 2019). Therefore, its conservation status should be carefully tracked in the southeastern Pacific given that seven out of the eight records in Peru and Ecuador come from fishery bycatch and that the fishing effort in these countries has been increasing for many decades.

In conclusion, the new reports of $M$. pelagios confirm the presence of this species of shark in Peruvian waters, add information to expand its known distribution range, and raise concern about the need for carefully monitoring its interactions with fisheries in the southeastern Pacific.

\section{Acknowledgements}

We give our thanks to N. Cristiano, A. Torrejon, and N. Hernandez who helped collect data in the field, to the fishers from Los Organos who allowed us to study one of their specimens; to the fishers from Mancora, especially to captain H. Lazo and his crew, J. Olivos, H. Aponte, J. Flores, and J. Becerra, for their kindness and for allowing ATC to board their vessel to collect data; to D. Ebert for the identification of the specimens and advice; to the BioAl SAC research center and its director, M. Santa Maria; to C.R. Gonzalez and D. Huerta for preparing the map; to K. Bennett and D. Biffi for proofreading the manuscript; and to the reviewers for helping to improve the manuscript. ATC was funded by the New England Aquarium and Ocean Classrooms.

\section{Authors' Contributions}

RMN, AMP, OCM, and ATC conducted fieldwork and collected data; SKS compiled the data and wrote the paper; RMV and AMP assisted in writing the paper; all authors revised the manuscript.

\section{References}

Alfaro-Cordova E, Del Solar A, Gonzalez-Pestana A, Acuña-Perales N, Coasaca J, Cordova-Zavaleta F, Alfaro-Shigueto J, Mangel JC (2018) Isotopic niches of four commercially important pelagic elasmobranch species captured by the small-scale driftnet fishery of northern Peru. Latin American Journal of Aquatic Research 46 (2): 482-488. https://doi.org/10.3856/vol46-issue2-fulltext-24

Aronés K, Ayón P, Hirche H-J, Schwamborn R (2009) Hydrographic structure and zooplankton abundance and diversity off Paita, northern Peru (1994 to 2004)_ENSO effects, trends and changes. Journal of Marine Systems 7 (4): 582-598. http://doi.org/ 10.1016/j.jmarsys.2009.01.002

Ayón P, Criales-Hernandez MI, Schwamborn R, Hirche H-J (2008) Zooplankton research off Peru: a review. Progress in Oceanography 79 (2-4): 238-255. https://doi.org/10.1016/j.pocean.2008.10.020

Castillo-Géniz JL, Ocampo-Torres AI, Shimada K, Rigsby CK, Nicholas AC (2012) Tiburón bocudo juvenil, Megachasma pelagios, capturado en la costa del Pacífico de México, y su relevancia para la diversidad de los peces condrictios en México. Ciencias Marinas 38 (2): 467-474.

Castro JI (1983) The sharks of North America. Texas A\&M University Press, College Station, Texas, 180 pp.

Compagno LJV (2001) Sharks of the world. An annotated and illustrated catalogue of shark species known to date. Volume 2. Bullhead, mackerel and carpet sharks (Heterodontiformes, Lamniformes and Orectolobiformes). FAO Species Catalogue for Fishery Purposes. No. 1, Vol. 2. FAO, Rome, 269 pp.

Compagno L, Dando M, Fowler S (2005) Guía de campo de los tiburones del mundo. Ediciones Omega, Barcelona, 357 pp.

Dulvy NK, Fowler SL, Musick JA, Cavanagh RD, Kyne PM, Harrison LR, Carlson JK, Davidson LNK, Fordham SW, Francis MP, Pollock CM, Simpfendorfer CA, Burgess GH, Carpenter KE, Compagno LVJ, Ebert DA, Gibson C, Heupel MR, Livingstone SR, Sanciangco JC, Stevens JD, Valenti S, White WT (2014) Extinction risk and conservation of the world's sharks and rays. eLife 3: e00590. https://doi.org/10.7554/eLife.00590

Ebert DA, Fowler S, Compagno L (2013) Sharks of the world. A fully illustrated guide. Wild Nature Press, Plymouth, 528 pp.

Fischer J, Erikstein K, D’Offay B, Barone M, Guggisberg S (2012) Review of the implementation of the International Plan of Action for the Conservation and Management of Sharks. FAO Fisheries and Aquaculture Circular No. 1076, FAO, Rome, 120 pp. 
Gonzalez-Pestana A, Kouri JC, Velez-Zuazo X (2016) Shark fisheries in the southeast Pacific: a 61-year analysis from Peru [version 2; referees: 2 approved with reservations] F1000Research 3: 164 https://doi.org/10.12688/f1000research.4412.2

Gonzalez-Pestana A, Acuña-Perales N, Córdova F, Coasaca J, Alfaro E, Alfaro-Shigueto J, Mangel J (2019). Feeding habits of thresher sharks Alopias sp. in northern Peru: predators of Humboldt Squid (Dosidicus gigas). Journal of the Marine Biological Association of the United Kingdom 99 (3): 695-702. https://doi.org/10.1017/ S0025315418000504

Haight T (2019) Megachasma pelagios the Megamouth Shark. http:/ sharkmans-world.eu/mega.html. Accessed on: 2019-09-01.

HIDRONAV (2016) Boletin diario de las condiciones oceanograficas. Martes 22 de Noviembre. https://www.dhn.mil.pe/app/boletin diario/index.php?f=2016-11-22. Accessed on: 2019-11-12.

HIDRONAV (2018a) Boletin diario de las condiciones oceanograficas. Miercoles 11 de Julio. https://www.dhn.mil.pe/app/boletin diario/index.php?f=2018-07-11. Accessed on: 2019-8-20.

HIDRONAV (2018b) Boletin diario de las condiciones oceanograficas. Miercoles 25 de Julio. https://www.dhn.mil.pe/app/boletin diario/index.php?f=2018-07-25. Accessed on: 2019-8-20.

Ivanova NV, Zemlak TS, Hanner RH, Hebert PDN (2007) Universal primers cocktails for fish DNA barcoding. Molecular Ecology Notes 7: 544-548. https://doi.org/10.1111/j.1471-8286.2007. 01748.x

Kyne PM, Liu KM, Simpfendorfer C (2019) Megachasma pelagios. The IUCN Red List of threatened species 2019: e.T393 38A124402302. http://doi.org/10.2305/iucn.uk.2019-1.rlts.t39338 a124402302.en

Last PR, Stevens JD (1994) Sharks and rays of Australia. CSIRO, Melbourne, $513 \mathrm{pp}$.

Liu SYV, Joung SJ, Yu C-J, Hsu H-H, Tsai W-P, Liu KM (2018) Genetic diversity and connectivity of the megamouth shark (Megachasma pelagios). PeerJ 6: e4432. https://doi.org/10.7717/peerj.4432

Martínez-Ortiz J, Mendoza-Intriago D, Tigrero-Gonzalez W, FloresRivera G, López-Párraga R (2017) New records of megamouth shark, Megachasma pelagios off Ecuador, Eastern Pacific Ocean.
Ciencia Pesquera 25 (2): 27-30.

Mendoza A, Kelez S, Gonzales Cherres W, Maguiño R (2017) The Largetooth Sawfish, Pristis pristis (Linnaeus, 1758), is not extirpated from Peru: new records from Tumbes. Check List 13 (4): 261-265. https://doi.org/10.15560/13.4.261

Morrissey JF, Elizaga ET (1999) Capture of megamouth \#11 in the Philippines. The Philippine Scientist 36: 143-147.

Nelson DR, McKibben JN, Strong WR, Lowe CG, Sisneros JA, Schroeder DM, Lavenberg RJ (1997) An acoustic tracking of a megamouth shark, Megachasma pelagios: a crepuscular vertical migrator. Environtal Biology of Fisheries 49: 389-399. https://doi. org/10.1023/A:1007369619576

Passuni G, Barbraud C, Chaigneau A, Demarcq H, Ledesma J, Bertrand A, Castillo R, Perea A, Mori J, Viblanc V, Torres-Maita J, Bertrand S (2016) Seasonality in marine ecosystems: Peruvian seabirds, anchovy and oceanographic conditions. Ecology 97:182-193. https://doi.org/10.1890/14-1134.1

Romero M, Liza Santa Cruz J (2004) Megamouth caught for first time in the Pacific Ocean off the coast of South America. Confirmed Megamouth Shark sightings. Florida Museum. https://www.florida museum.ufl.edu/discover-fish/sharks/megamouths/. Accessed on: 2019-8-28.

Spalding MD, Fox HE, Allen GR, Davidson N, Ferdaña ZA, Finlayson M, Halpern BS, Jorge MA, Lombana A, Lourie SA, Martin KD, McManus E, Molnar J, Recchia CA, Robertson J (2007) Marine ecoregions of the world: a bioregionalization of coastal and shelf areas. BioScience 57: 573-583. https://doi.org/10.1641/ B570707

Taylor LR, Compagno LJV, Struhsaker PJ (1983) Megamouth - a new species, genus and family of lamnoid sharks, Megachasma pelagios (Family Megachasmidae), from the Hawaiian Islands. Proceedings of the California Academy of Sciences (Series 4) 43 (8): 87-110

Watanabe YY, Papastamatiou YP (2019) Distribution, body size and biology of the megamouth shark Megachasma pelagios. Journal of Fish Biology 95 (4): 992-998. https://doi.org/10.1111/jfb.14007 